\title{
Does tax competition make tax reform essential?
}

UDK: $336.27: 339.97$

\author{
Maja Klun \\ Fakulteta za upravo, Univerza v Ljubljani \\ maja.klun@fu.uni-lj.si
}

\begin{abstract}
Tax competition is generally defined as competition between national economies to increase their competitiveness and attract foreign investment by means of tax policy. Tax policy measures that tax mobile or foreign capital at significantly lower rates are known as harmful tax competition. Some recent corrections to the tax code and proposed tax amendments in Slovenia represent an attempt to relieve the burden on the taxpayer. This paper compares the taxation of high income taxpayers, low income taxpayers, taxpayers with passive income, and the taxation of businesses in Slovenia and neighbouring countries. The comparison indicates that Slovenian taxpayers with a high income have a higher tax burden than in neighbouring countries, while low income taxpayers have one of the highest burdens. The same applies to passive income. The tax burden on businesses ranks in the middle.
\end{abstract}

Key words: taxes, tax reform, globalisation, European Union, OECD.

\section{Introduction}

"Tax competition" is one effect of globalisation. Tax competition is generally defined as competition between national economies to increase their competitiveness and attract foreign investment by means of their tax policy. Tax policy measures that tax mobile or foreign capital at significantly lower rates are known as harmful tax competition. Although different global organisations (including OECD and EU) have continually warned of the negative consequences of harmful tax competition, they have recently also pointed out the positive effects of them. The fact is that over the past decade most countries have lowered their highest tax rates for personal income tax 
Maja Klun

Does tax competition make tax reform essential?

and have moved from a comprehensive income tax approach or offering special deductions for specific types of income (according to tax schedules) in favour of an approach (generally a dual system), in which capital income or gains is not taxed at progressive rates. Similar trends have also occurred in the taxation of corporate profits. A large number of Eastern European countries have abolished the progressive taxation of personal income and introduced a flat-tax rate, although the high social security contributions mean that one cannot truly speak of a flat-tax rate, but rather a special dual model for taxing working income.

Over the past three years, Slovenia has undergone almost continual change in its tax legislation as well as intense debate on the introduction of a flat tax rate. Although experts have not reached a common position on the tax reform (or the reform of the reform), there is a commonly held view that labour income is overtaxed, and particularly high, and that the tax burden on labour must be reduced. Slovenia is not isolated from globalisation and tax competition leads not only towards reducing the burden on income from employment, but also business income and income from capital.

This paper gives the results of different views on the existence of tax competition and relations with tax reforms. The main section of the paper compares the taxation of high income taxpayers, low income taxpayers, taxpayers with passive income, and the taxation of businesses in Slovenia and neighbouring countries.

\section{Different views on tax competition}

In the past the concept of tax competition was not part of the wider theoretical debate. Economies were relatively closed, and capital was less mobile. Increasing volumes of trade, the faster flow of information, increased mobility of production, and the removal of tax and non-tax-related restrictions on international business and investments, national tax systems has become an important element in decisions on the location of businesses and investments. Textbooks on public finances do not place particularly emphasis on tax competition, with the term appearing most frequently in relation to the Tiebout model, which indicates that people emigrate to countries with the best living conditions in terms of public goods, including tax. Globalisation has led to massive changes in mobility and the issue has therefore become more relevant. The first debates were on harmful tax competition, which is by definition a tax policy measure that significantly lowers the taxation of mobile 


\section{Does tax competition make tax reform essential?}

or foreign capital (OECD, 1998). The transfer of domicile to countries with favourable income tax rules, and the transfer of a company's registered office to a country with low tax rates for profit and capital, is today common practice among wealthy individuals and large companies respectively. The OECD therefore passed a number of recommendations and proposals to counteract harmful tax competition, and also started to publish a list of countries that do not respect the recommendations. In $1998 \mathrm{EU}$ finance ministers changed the corporate tax code. In its 1999 report it identified 66 tax measures as harmful tax competition, with 40 such measures being identified in EU member states. The EU is therefore working to eliminate harmful tax competition, primarily through tax harmonisation, but this process is slow and there is significant resistance from member states. Tax harmonisation is a process that does not just eliminate harmful tax competition, but is also an attempt to restrict any tax competition at all. It would be difficult to set a precise boundary between harmful tax competition and tax competition, as both cases involve more favourable taxation for taxpayers. The essential difference between the two is essentially that harmful tax competition is largely aimed at attracting foreign capital, income and assets through low or zero tax rates and creating special forms of taxations for individual forms of capital, particularly foreign capital. Tax competition, however, can be generally defined as tax policy measures to increase the competitiveness of a domestic economy (see Drezgić, 2005).

Wilson and Wildasin (2004) listed the consequences of tax competition, based on definitions from a number of authors:

- tax competition leads to the effective distribution of companies into different regions;

- tax competition reduces the state's participation in the economy and its influence over general prosperity;

- tax competition shifts the tax burden from mobile to immobile capital;

- reducing some tax rates mitigates progressiveness and hence the distributory function of public finances.

The OECD (1998) largely points to the negative consequences of tax competition, as it leads to potential disturbances in business and investment, and reduces global prosperity. Changing tax systems affects the national tax revenue potential (e.g. capital flow, leading to reduced employment) and changes the tax structure (higher taxation of non-mobile subjects), and reduces the distributory effect of taxes, which has a negative impact on society. OECD is therefore in favour of harmonising tax systems rather than tax competition. 


\section{Maja Klun}

\section{Does tax competition make tax reform essential?}

McGee (2004) offers a completely different view of tax competition. Tax harmony, he asserts, is an attempt by rich countries to maintain high tax rates and to finance social programmes. Globalisation is therefore a positive trend, offering greater opportunities to invest anywhere in the world. Companies have the opportunity to select the site of their investments where the tax system is most favourable, which enhances their competitiveness. Countries with low tax rates record higher economic growth, not only due to attracting foreign investment, but also because more capital and revenues remain in the private sector, which uses funds more efficiently than the state.

\section{Tax competition and tax reform}

Tax reform in most countries is largely due to tax competition, as most reforms lead to an expansion of the tax bases (mainly to include worldwide income, whereby an attempt is made to tax income generated in countries with more favourable tax codes), and the reduction of tax rates. Tax reforms cover personal income tax as well as corporate income taxation. Most countries work to create a competitive fiscal environment, which promotes investment, assumption of risk and entrepreneurship, while on the other hand wanting to make the tax system simpler and fairer. As mentioned, most countries have expanded the tax base and reduced the level of taxation. In the taxation of personal income there is a clear trend to move from a comprehensive taxation system towards a schedular or more accurately a dual income taxation system. OECD member states have a varied tax structure as the importance of direct taxation differs from country to country. The ratio of income tax to total tax revenue varies from just over 10\% (Slovakia) to over 50\% (Denmark). Despite the different proportions, between 2000 and 2005 the tax burden on salaries fell on average for all salary categories in OECD countries. According to OECD (2006) data, over this period the taxation of the lowest salaries fell by 0.8 percentage points, while taxation on the highest salaries fell by 0.7 percentage points. The top marginal tax rate over the period ranged from $47 \%$ (average top marginal tax rate in OECD countries in 2000) to $43.3 \%$ (2005). There was also a significant reduction in the number of tax brackets and the move towards a dual taxation system. The dual income tax system means that capital income is taxed at a flat tax rate, and not with progressive rates like other income. Although in the past one could not speak of a comprehensive income tax system, as most countries had a special tax 
regime for specific types of income (recognising different costs and deductions for different income types), all income was still taxed using a progressive scale.

The lowest top marginal tax rate for personal income tax is in Slovakia, where it is $19 \%$ (the flat tax rate), while the highest is in Denmark, where it is $59 \%$. The average top marginal tax rate in the EU is $41.7 \%$ - in the EU15 it is $47.19 \%$ while in the new 10 states the average is $32.6 \%$. Austria, Belgium and Slovenia all have a top rate of $50 \%$, while the Netherlands (52\%), Finland $(52.12 \%)$ and Sweden $(56.5 \%)$ all have rates above $50 \%$ as well as Demark. Dual taxation systems are found in Austria, Belgium, the Czech Republic, Denmark, Hungary, Italy, Lithuania, the Netherlands, Poland, Sweden and the UK (for more see Blažić and Bašagić, 2005).

There is also a trend towards reducing tax rates in the taxation of corporate income tax. Of considerable interest are studies indicating that if a country lowers its tax rate by $1 \%$, then foreign direct investment amount increases by $3.3 \%$ to $4.3 \%$ (Drezgić, 2005). OECD studies have shown that over the period 1985-1994 the number of direct investments in Caribbean islands and islands in the South Pacific increased fivefold, and reached USD 200 billion (OECD, 1998).

\section{Slovenia and its neighbouring countries}

In the last two years Slovenia has witnessed the continual reform of its tax system. In 2004 a large-scale reform of personal income tax, corporate income tax and the tax process was carried out. Soon after the changes were introduced it became clear that they included a number of deficiencies. Some corrections were then made, and more changes will follow in 2007. One such correction to the income tax system, which actually came into force before the 2005 changes, was the taxation of capital gains from shares forming a substantial shareholding, as it was clear that unfavourable taxation of capital gains would lead to capital flow away from Slovenia. Most substantial shareholders sold shares to newly established companies abroad, mainly in favourable tax regimes.

Ignoring the existence of tax competition therefore had negative consequences for Slovenia's tax system. The correction of the 2004 reforms recognised the existence of tax competition, and was aimed at increasing the competitiveness of the Slovenian economy and simplifying tax procedures. IMD 


\section{Maja Klun}

\section{Does tax competition make tax reform essential?}

world competitiveness 2005 yearbook listed 20 weakest criteria in Slovenia among which 5 were connected with taxation (employee's social security contribution rate, effective personal income tax rate, collected total tax revenues, investment incentives and real personal taxes), while corporate tax rate on profit was listed as one of 20 strongest criteria.

To make it easier to evaluate the changes made to tax legislation over the last year and the changes forecast for this year, the paper will now review personal income tax and corporate income tax in Slovenia's four neighbouring countries (Austria, Croatia, Hungary, Italy), which may be seen as direct competitors to the Slovenian tax system. It remains true, of course, that today's globalisation process does not limit competition to neighbouring countries alone, particularly in relation to mobile capital.

\subsection{Personal income tax}

In all four neighbouring countries personal income is taxed according to the global income principle with a progressive scale. All four countries also have some form of dual system (some forms of income taxed at a set final rate). Slovenia and Austria have the highest marginal tax rate, followed by Croatia, Italy and Hungary. Slovenia has the highest number of tax brackets, while Hungary has the lowest. Austria's bottom marginal tax rate is the lowest, while Italy has the highest bottom rate (see Table 1). Table 1 indicates that taxpayers in Slovenia reach the top tax bracket more quickly than taxpayers in Austria, while taxpayers with the lowest income exceed the first tax bracket relatively quickly. Italy, where the lower threshold is highest, also has the highest bottom marginal tax rate, however this is somewhat mitigated by the allowance system.

All countries allow certain expenses to be used to lower the tax base, especially those relating to education and various forms of health insurance and additional pension saving. Austria permits a set percentage of expenses, but also sets a maximum amount for the allowance. Other countries set a maximum amount for individual allowance groups, except for donations in Croatia for which there is a set percentage. Slovenia has a set percentage without a maximum amount for some forms of income. Croatia offers general allowances in the form of a reduced tax base that differ according to the taxpayer category (employee, pensioner, the region of residence), while Italy also has different allowances for different taxpayer groups, though they only apply to people not exceeding a set income limit (e.g. EUR 33500 for 
employees in 2006). Their tax allowance system also allows employees not exceeding the general allowance limit of EUR 7500 to remain untaxed. This mitigates the high bottom marginal tax rate. A similar system applies in Slovenia and Croatia, however in Slovenia there is a general allowance for all taxpayer groups, and then specific allowances available for different groups. In both countries this allowance is significantly lower than in Italy; in 2006 it was EUR 2552 in Slovenia and EUR 2656 in Croatia. Slovenia, Croatia and Italy also permit tax allowances for dependent family members, with set amounts reducing the tax base. All forms of tax allowance mentioned above involve reducing the tax base.

Table 1: Personal income tax in 2006 for Slovenia and four neighbouring countries

\begin{tabular}{|lccccc|}
\hline Country & $\begin{array}{c}\text { Top marginal } \\
\text { tax rate (\%) }\end{array}$ & $\begin{array}{c}\text { Lower margin } \\
\text { for top income } \\
\text { tax bracket } \\
\text { EUR }{ }^{1} \text { (in }\end{array}$ & $\begin{array}{c}\text { Number } \\
\text { of tax } \\
\text { brackets }\end{array}$ & $\begin{array}{c}\text { Lowest } \\
\text { marginal tax } \\
\text { rate (\%) }\end{array}$ & $\begin{array}{c}\text { Upper margin } \\
\text { for lowest tax } \\
\text { bracket (EUR) }\end{array}$ \\
\hline Austria & 50 & 51000 & 4 & 0 & 10000 \\
\hline Croatia & 45 & 37178 & 4 & 15 & 5311 \\
\hline Italy & 43 & 100000 & 4 & 23 & 26000 \\
\hline Hungary & 36 & 5556 & 2 & 18 & 5556 \\
\hline Slovenia & 50 & 44012 & 5 & 16 & 5539 \\
\hline Slovenia* & 41 & 13600 & 3 & 16 & 6800 \\
\hline
\end{tabular}

Vir: IBFD, European Tax Surveys, 2006

* in 2007

Austria has a general allowance (as well as specific allowances for different groups), and allowances for dependents, while employees can also have expenses for travel to work recognised. All allowances are set amounts, with some amounts reducing the tax base, while other reduced the tax liability (tax credits). It is a combination of two forms of allowance with the same purpose. Italy and Hungary also offer tax credits that reduce tax for various

1 The following exchange rates apply: one euro is equivalent to 239.64 Slovenian tolars; 7.23 Croatian kunas and 278.99 Hungarian forints. 
Maja Klun

\section{Does tax competition make tax reform essential?}

expenses and income up to a maximum amount, however in Hungary income tax payers with income over EUR 23300 are not entitled to these credits for expenses, and the same applies to individual expenditure, as there are also maximum income limits after which these credits do not apply. The only tax credit in Slovenia that actually reduces the tax liability is for pensioners (IBFD, 2006).

As the allowance system differs between these countries, it is difficult to draw a direct comparison for individual taxation. Nevertheless, the paper sets out below the tax liabilities for an individual with a high income and with a low income. To simplify the comparison, it involves a taxpayer whose income derives solely from a salary, who is single without children and who does not claim tax allowances and credits for various expenses. Table 2 gives a calculation of the income tax return in each country for an individual with high income, when the net tax base is EUR 46000 (income tax calculated according to the tax brackets for each country only), and when the taxable income is EUR 46000 (general allowance taken into consideration).

Table 2: Tax liability of high income individual

\begin{tabular}{|ccc|}
\hline Country & Net tax base EUR 46 000 & $\begin{array}{c}\text { Taxable income EUR 46 000 (general } \\
\text { allowance considered) }\end{array}$ \\
\hline Austria & 14905 & 14503 \\
\hline Croatia* & 15123 & 13928 \\
\hline Italy* & 13300 & 13300 \\
\hline Hungary & 15560 & 15576 \\
\hline Slovenia & 16788 & 15060 \\
\hline Slovenia** & 16208 & \\
\hline
\end{tabular}

*excluding local taxes

** in 2007

The table shows that in both cases the tax liability for an individual is highest in Slovenia, despite the fact that in Italy and Hungary taxpayers earning over a set taxable income are not eligible for the general allowance. The difference in taxation between Slovenia and rest in the first example is as much as EUR 3000, and in all cases is over EUR 1000. Higher earners in 


\section{Does tax competition make tax reform essential?}

Slovenia are therefore taxed much more than in neighbouring countries. The tax changes in 2007 does not drasticly change situation.

The position of taxpayers with a lower income is different. They face the heaviest tax burden in Hungary - if the general allowance is considered - or in Italy if one considers the net tax base, as Italy has the highest bottom marginal tax rate. A Slovenian taxpayer with a net tax base of EUR 5500 is in third place in this comparison, paying over EUR 300 less than the Italian taxpayer and EUR 100 less than the Hungarian, however the Italian's taxable income is much higher than the Slovene's in that case. Taking the general allowance into account and fixing the taxable income at EUR 5500, the Slovenian taxpayer pays just over EUR 100 less than the Hungarian, somewhat more than the Croatian, while the Austrian and Italian taxpayer actually pay no tax. A taxpayer not reaching a taxable income of EUR 2522 (the general allowance in Slovenia), is not taxed in any country except Hungary, where income tax of EUR 216 would still have to be paid.

Table 3: Tax liability of low income individual

\begin{tabular}{|ccc|}
\hline Country & Net tax base EUR 5500 & $\begin{array}{c}\text { Taxable income EUR 5500 (general } \\
\text { allowance considered) }\end{array}$ \\
\hline Austria & 0 & 0 \\
\hline Croatia* & 844 & 427 \\
\hline Italy* & 1.265 & 0 \\
\hline Hungary & 990 & 603 \\
\hline Slovenia & 880 & 476 \\
\hline Slovenia** & 880 & 432 \\
\hline
\end{tabular}

*excluding local taxes

** in 2007

In all countries, taxpayers pay social contributions defined according to income levels. The rates differ and range from 10\% (Italy) to 22.5\% (Slovenia). The highest income at which contributions are still paid is fixed in Austria and Croatia, while in Hungary there is a minimum daily amount required for pension contributions. Social security contributions already paid are not part of the tax base for personal income tax in any of the countries.

The salary burden is determined by taking into account the average rate of income tax and social security contributions (employees and employers) and 


\section{Maja Klun}

\section{Does tax competition make tax reform essential?}

is given by Eurostat for EU members for low incomes, and by the OECD for average and low and high incomes. According to OECD data for 2005 (for Austria, Italy and Hungary) the tax wedge on average production salaries is highest in Hungary (49.2\%), and lowest in Italy (45.4\%), while in Austria it was $47.4 \%$ (OECD Tax Database, 2006). If the tax wedge on the average salary in Slovenia and Croatia is assessed in a similar manner, the values would be higher than $50 \%$ in Slovenia and less in Croatia. This reveals that Slovenia has the highest tax wedge for average earner. As initially mentioned, all countries observed have some form of dual taxation system. The introduction of the dual system in Slovenia from 2006 brought Slovenia's system into line with its neighbours.

Austria has a final income tax rate of $25 \%$ for dividends and taxable interest. Capital gains generated from the sale of shares and other securities after being held for one year and real estate held for 10 years is not taxed, while other capital gains and capital gains from the sale of shares that form substantial shareholding are taxed according to a progressive scale.

In Croatia dividends will not be taxed from 2006 onwards, taxable interest (primarily interest on loans) are taxed at a final rate of $35 \%$, while capital gains from the sale of real estate are not taxed after being held for three years. The sale of real estate before the three-year time limit is taxed with a final rate of $25 \%$. Capital gains from the sale of movable property and securities are not subject to tax.

In Italy dividends held by small shareholders are taxed at a final rate of $12.5 \%$, while dividends from substantial shareholding are taxed according to a progressive scale, however dividends received are eligible for an allowance of $60 \%$. A similar regime applies to capital gains generated from the sale of shares and other securities. Capital gains generated from the sale of real estate become tax exempt when the taxpayer has owned the property for over five years, otherwise a progressive scale applies. Interest is taxed at a final rate of $27 \%$, except for interest on lending which is taxed according to a progressive scale, and interest on government and other bonds, which is taxed at $12.5 \%$.

In Hungary a total of $30 \%$ of dividends are taxed at a final rate of $25 \%$, while the remaining dividends are taxed at a final rate of $35 \%$. There is a zerotax rate on interest, except for interest on loans to companies, if they exceed a set amount. Capital gains from the sale of shares and other securities are taxed at a final rate of $25 \%$, capital gains from the sale of real estate are also taxed at $25 \%$, but the rate reduces by $10 \%$ after six years' ownership, and reduces by a further $10 \%$ each year after that so there is no tax on real estate owned for more than 15 years. Hungary is planning changes for 2007, setting the final income tax rate for interest and capital gains at $20 \%$. 
In Slovenia, dividends, taxable interest and capital gains are taxed at a flat final rate of $20 \%$. This level is only reduced for capital gains depending on the length of ownership, with no taxation after 20 years. Although the level is generally lower than in other countries, one can conclude that capital gains from the sale of real estate are subject to a less favourable tax regime, as they only become tax exempt after 20 years, with the period being shorter in the other four countries. Dividends are taxed higher in Austria and Hungary, interest higher in Austria and Croatia, and on some forms of interest in Italy. Austria has the most favourable tax regime for capital gains from the sales of shares after a period of year (unless they form a substantial shareholding), followed by Croatia (with exemption after three years' ownership), followed by Slovenia at $20 \%$, which offers exemption after 20 years (IBFD, 2006).

The table below gives a country-by-county comparison for an individual with the following income:

- A: EUR 200 dividends (not from substantial shareholding);

- B: EUR 200 interest on time deposit;

- C: EUR 500 capital gains from sale of real estate (owned for 5.1 years)

- D: EUR 500 capital gains from sale of real estate (owned for 15.1 years);

- E: EUR 200 capital gains from sale of shares (not from substantial shareholding; owned for 1.1 years);

- F: EUR 200 capital gains from sale of shares (not from substantial shareholding; owned for 3.1 years).

Table 4: Taxation of dividends, interest and capital gains

\begin{tabular}{|lrrrrc|}
\hline Income & Austria & Croatia & \multicolumn{1}{c}{ Italy } & Hungary & Slovenia \\
\hline A & 50 & 0 & 25 & 64 & 40 \\
\hline B & 50 & $0^{2}$ & 54 & 0 & $0^{3}(40)$ \\
\hline C & $0^{1}$ & 0 & 0 & 125 & 100 \\
\hline D & 0 & 0 & 0 & 0 & 25 \\
\hline E & 0 & $0^{2}$ & 25 & 50 & 40 \\
\hline F & 0 & 0 & 25 & 50 & 40 \\
\hline Total & 100 & 0 & 129 & 289 & $245(285)$ \\
\hline
\end{tabular}

${ }^{1}$ Austria: EUR 500 is taxable on a progressive scale, but the bottom marginal tax rate is $0 \%$. ${ }^{2}$ Croatia: interest on savings and capital gains from selling securities are tax exempt. ${ }^{3}$ Slovenia: up to SIT 300000 tax exempt in 2006 and up to SIT 150000 in 2007; after 2008 interest will be taxed in full (values in bracket). 
Maja Klun

\section{Does tax competition make tax reform essential?}

\subsection{Corporate income tax}

When Slovenia introduced corporate income tax it emphasised that its $25 \%$ rate was one of the lowest in Europe. However, the limit has never been changed, while its fellow new EU member states significantly lowered their rates before EU entry. Cyprus lowered its rate from 25\% to 10\%, Latvia from $22 \%$ to $15 \%$, Lithuania from $24 \%$ to $15 \%$, Poland from $34 \%$ to $19 \%$, the Czech Republic from $31 \%$ to $28 \%$, Hungary from $17.5 \%$ to $16 \%$, and Slovakia from $29 \%$ to $19 \%$. In addition to these countries (excluding the Czech Republic), Ireland (12.5\%) and Estonia are also among the EU countries with the lowest corporate tax rate. Although other countries do not have lower tax rates, they have nevertheless been lowered in other countries (e.g. in Austria from $34 \%$ to $25 \%$ in 2005 ).

Of all the countries observed, Italy has the highest corporate tax rate, while Hungary has the lowest. Austria has the same rate as Slovenia, but in addition to the tax rate there is a minimum tax contribution that companies must pay, depending on their legal status. The rates are given in Table 5.

Table 5: Tax rates for corporate income tax

\begin{tabular}{|lc|}
\hline Country & Tax rate \\
\hline Austria & 25 \\
\hline Croatia & 20 \\
\hline Italy & 33 \\
\hline Hungary & 16 \\
\hline Slovenia & 25 \\
\hline Slovenia* & 23 \\
\hline
\end{tabular}

Source: IBFD, European Tax Surveys, 2006

* in 2007

All the observed countries recognise a range of allowances and incentives when defining the tax base. Austria permits accelerated depreciation, allowances for expenditure on research and development, employee training and new share issues. All the incentives have a maximum allowance limit. 
Croatia offers allowances for entertainment expenses, employment and donations, and a range of incentives for new companies and investments, as in some circumstances companies can pay at a lower tax rate. Lower tax rates apply to set regions and free zones. In Hungary companies can make use of allowances for investments, employment and expenditure on research and development. Most of these have a maximum specified amount. Under certain conditions companies may also be eligible for a lower tax rate. In Italy, in addition to a set percentage for entertainment expenses, there are also allowances for employment and research. Accelerated depreciation is permitted and there is an allowance limit for reserves. Slovenia has similar allowances and incentives to its neighbours, offering allowances for set costs of entertainment expenses, as well as allowances for donations, investments, employment, and research and development. Slovenia according to stated do not differ much from other neighbouring countries.

\section{Conclusion}

Predictions of what form the latest changes to Slovenia's tax code will take suggest that the existence of tax competition is no longer seen as negligible, as most of the changes tend towards simplifying and reducing tax rates, and - for personal income tax - reducing the number of tax brackets. Reducing the top marginal tax rate will reduce the burden on higher earners, which the comparison has shown are taxed highest in Slovenia. The lowering of the bottom marginal tax rate, even if the general allowance were raised to one million tolars (EUR 4173), would leave lower earners significantly worse off, particularly in comparison to Italy and Austria, where many Slovenes living in border areas already work.

Increasing the standard VAT rate to over $20 \%$ could also have a negative impact, as none of the neighbouring countries has a higher rate at present. Italy, Austria and Hungary all have two reduced VAT rates, while Croatia even has a zero rate for essential goods.

It does not make sense when preparing tax legislation to worsen the position of taxpayers that are currently in a comparable position at least with neighbouring countries, while it does make sense to improve the position of those currently in a poorer comparable position, i.e. those earning higher incomes. 


\section{Maja Klun}

\section{Does tax competition make tax reform essential?}

Doc. dr. Maja Klun je julija 2002 uspešno zagovarjala doktorsko disertacijo in tako pridobila naziv doktorja znanosti s področja ekonomije, leta 2005 pa je bila prvič izvoljena $v$ docentko za področje ekonomike javnega sektorja. Njena poglavitna raziskovanja so s področja davkov, ciljno usmerjenega proračuna in merjenja uspešnosti in učinkovitosti v javnem sektorju.

\section{References}

- Blažić H., Bašagić D. (2005): „Dividend Taxation: The Comparative Analysis with Emphasis on Slovenia and Croatia«, Uprava, III, No 1, pp. 83-100.

- Drezgić S. (2005): „Harmful Tax Competition in the EU with Reference to Croatia«, časopis za ekonomsku teoriju i praksu, 23, No 1, pp. 71-100.

- IBFD (2006): »European Tax Surveys«, IBFD: Amsterdam.

- McGee R.W. (2004): „Is Tax Competition Harmful? « Andreas School of Business Working Paper Series, Barry University: Miami.

- OECD (1998): „Harmful Tax Competition: An Emerging Global Issue«, OECD: Paris, www.oecd.org.

- OECD (2006): »Reforming Personal Income Tax«, The OECD Policy Brief, March 2006, www.oecd.org/publications/Policybriefs.

- OECD Tax Database (2006): „Taxation of Wage Income«, OECD: Paris, www.oecd.org.

- Wilson J.D., Wildasin D. E. (2004): "Capital Tax Competition: Bane or Boon", Journal of Public Economics, No 88, pp. 1065-1091. 


\section{POVZETEK}

\section{Ali je davčna reforma nujna zaradi "davčne» konkurence?}

Proces globalizacije povzroča med drugim tudi "davčno konkurenco". Davčna konkurenca je splošno definirana kot tekmovanje nacionalnih gospodarstev za povečanje njihove konkurenčnosti in privabljanja tujih investicij s pomočjo davčne politike. Ukrepi davčne politike, ki bistveno nižje obdavčujejo mobilni kapital ali tuji kapital, so označeni kot škodljiva davčna konkurenca. Čeprav različna svetovna združenja in organizacije (tudi OECD in EU) stalno opozarjajo na negativne posledice škodljive davčne konkurence, se $v$ zadnjem času poudarjajo tudi pozitivni učinki lete. Dejstvo je, da je večina držav $v$ zadnjem desetletju znižala najvišje davčne stopnje pri obdavčenju dohodkov posameznikov in odstopila od celovitega ali prikrito cedularnega pristopa obdavčevanja dohodkov posameznikov, in sicer $v$ smeri cedularnega (večinoma dualnega) pristopa, $v$ katerem dohodki iz kapitala niso obdavčeni po progresivnih stopnjah. Podobni trendi se pojavljajo tudi pri obdavčevanju dobičkov podjetij. Veliko število vzhodnoevropskih držav je odpravilo progresivno obdavčenje dohodkov posameznikov in uvedlo enotne davčne stopnje, čeprav pri še vedno visokih prispevkih za socialno varnost ne moremo govoriti o enotni davčni stopnji, ampak o posebnem dualnem modelu obdavčevanja delovnih dohodkov.

$V$ Sloveniji smo $v$ zadnjih treh letih soočeni praktično $z$ nenehnim spreminjanjem davčne zakonodaje ter polemikami o uvedbi enotne davčne stopnje. Čeprav med strokovnjaki ni enotnega stališča o davčni reformi (ali reformi reforme), velja enotno mnenje, da so delovni dohodki davčno preobremenjeni, posebej visoki in je zato razbremenitev dela nujna. Slovenija ni izolirana enota $v$ procesu globalizacije in davčna konkurenca vodi do teženj razbremenitve ne samo dohodkov, ki izhajajo iz zaposlitve, ampak tudi razbremenitev dohodkov podjetij in dohodkov, ki izhajajo iz kapitala.

V prispevku so prikazani različni pogledi na obstoj davčne konkurence ter povezanost $z$ davčnimi reformami. Osrednji del prispevka prikazuje primerjave obdavčenja zavezanca $\mathrm{v}$ Sloveniji in $\mathrm{v}$ njenih sosednjih državah (Avstriji, Hrvaški, Italiji in Madžarski). 
Maja Klun

Does tax competition make tax reform essential?

$V$ vseh sosednjih državah je dohodek fizičnih oseb obdavčen po načelu svetovnega dohodka in $\mathrm{s}$ progresivno lestvico (stopničasta progresija). $V$ vseh državah imajo določeno obliko dualnega sistema (nekateri dohodki so obdavčeni s končnim davkom). Najvišjo mejno davčno stopnjo imata Slovenija in Avstrija, sledijo Hrvaška, Italija in Madžarska. Slovenija ima največ davčnih razredov, najmanj pa Madžarska. Najnižjo spodnjo mejno davčno stopnjo ima Avstrija, najvišjo pa Italija. Davčni zavezanci v Sloveniji hitreje dosežejo zgornjo mejo obdavčitve kot zavezanci $v$ Avstriji, po drugi strani pa zavezanci z najnižjimi dohodki relativno hitro presežejo prvi dohodninski razred. $\vee$ vseh državah priznavajo določene izdatke, ki znižujejo davčno osnovo, predvsem za izobraževanje in različne oblike zdravstvenih zavarovanj in dodatnih pokojninskih zavarovanj. V Avstriji so določeni odstotki izdatkov, ki se priznajo, vendar pa je istočasno določen tudi maksimalni znesek olajšave. $V$ drugih državah so določeni maksimalni zneski za posamezno skupino olajšav, razen za donacije $v$ Hrvaški, kjer je določen odstotek. $V$ Sloveniji imamo določene odstotke brez zgornjih omejitev pri nekaterih dohodkih. Ker je sistem olajšav $v$ državah različen, je primerjavo obdavčenja posameznika težko enostavno prikazati. Zaradi poenostavitve primerjave gre za zavezanca, ki ima edini dohodek plačo, je samski, brez otrok in ne uveljavlja olajšav za različne izdatke. $V$ članku je prikazan izračun dohodnine $v$ posamezni državi za posameznika z visokimi dohodki, in sicer $v$ primeru, ko je njegova neto davčna osnova 46.000 EUR (zgolj izračun dohodnine glede na lestvico $v$ posamezni državi) in ko je njegov obdavčljivi dohodek 46.000 EUR (upoštevana je splošna olajšava). Iz izračuna je razvidno, da je $v$ obeh primerih davčna obremenitev zavezanca najvišja v Sloveniji, kljub temu, da Italija in Madžarska ne priznavata splošne olajšave za zavezance, ki presežejo določen obdavčljivi dohodek. Razlika $v$ obdavčitvi $v$ prvem primeru presega 3.000 EUR in ni manjša od 1.000 EUR, če upoštevamo prvi primer. Visoki zaslužki v Sloveniji so torej bistveno bolj obdavčeni kot $v$ sosednjih državah. Drugačen je položaj zavezancev z nizkimi dohodki. Ti so najbolj obdavčeni $v$ Madžarski, ko upoštevamo splošno olajšavo ter $v$ primeru neto davčnih osnov $v$ Italiji, ki ima tudi najvišjo spodnjo mejno davčno stopnjo. Slovenski zavezanec je $z$ neto davčno osnovo $v$ višini 5.500 EUR na tretjem mestu in plača dobrih 300 EUR manj kot italijanski zavezanec in 100 EUR manj kot madžarski, vendar pa je obdavčljivi dohodek pri italijanskem zavezancu precej višji kot pri slovenskem $v$ tem primeru. V kolikor upoštevamo splošno olajšavo in določimo 5.500 EUR kot obdavčljivi dohodek, pa slovenski zavezanec plačuje le dobrih 100 
EUR manj kot madžarski, nekoliko več od hrvaškega, medtem ko avstrijski in italijanski zavezanec ne plačata davka.

$\checkmark$ vseh državah zavezanci plačujejo socialne prispevke, ki so določeni $v$ stopnjah od dohodka. Stopnje so različne, in sicer se gibljejo med $10 \%$ ( $v$ Italiji) in 22,5\% (v Sloveniji). Najvišji dohodek od katerega se še plačujejo prispevki je določen $v$ Avstriji in Hrvaški, $v$ Madžarski pa je določen minimalni dnevni znesek za pokojninsko zavarovanje. Plačani prispevki za socialno varnost niso del davčne osnove za dohodnino $v$ nobeni državi.

Kot je že omenjeno v začetku, vse obravnavane države poznajo dualni sistem obdavčitve. Uvedba dualnega sistema v Sloveniji z letom 2006 je približala slovensko obdavčitev sosednjim državam. Čeprav je stopnja večinoma nižja kot $v$ drugih državah, pa lahko zaključimo, da so kapitalski dobički od prodaje nepremičnin manj ugodno obravnavani v Sloveniji, saj so neobdavčeni šele po 20 letih, $v$ vseh drugih obravnavanih državah pa je ta doba krajša. Dividende so bolj obdavčene $\vee$ Avstriji in Madžarski, obresti pa $v$ Avstriji, Hrvaški in nekatere $v$ Italiji. Kapitalski dobički od prodaje vrednostnih papirjev so po preteku enega leta lastništva najugodneje davčno obravnavani $v$ Avstriji (če ne gre za pretežne lastniške deleže), sledi Hrvaška (z oprostitvijo po treh letih lastništva), z 20 \% stopnjo jima sledi Slovenija, ki tudi omogoča oprostitev po 20 letih lastništva.

Od vseh obravnavnih držav ima najvišjo davčno stopnjo obdavčenja dobička podjetij Italija, nižjo od Slovenije pa imata Madžarska in Hrvaška. Vse države poznajo podobne olajšave in vspodbude, tako da $v$ primeru obdavčenja podjetij Slovenija ne izstopa. 